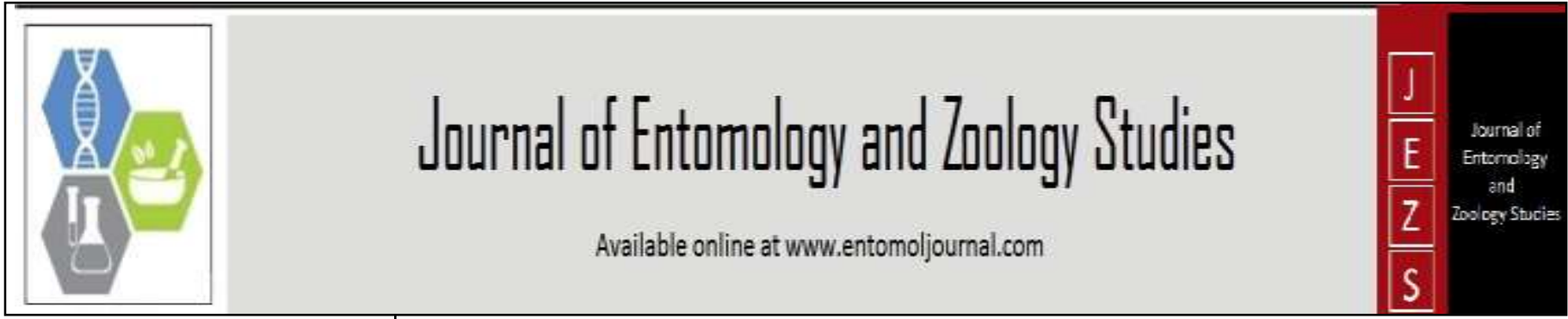

E-ISSN: 2320-7078

P-ISSN: 2349-6800

www.entomoljournal.com

JEZS 2021; 9(4): 422-425

(C) 2021 JEZS

Received: 07-05-2021

Accepted: 09-06-2021

Panuganti Shirisha

M.Sc. (Ag.) Entomology,

Department of Entomology, Sam

Higginbottom University of

Agriculture, Technology and

Sciences, Prayagraj, Uttar

Pradesh, India

Ashwani Kumar

Associate Professor,

Department of Entomology,

Sam Higginbottom University of

Agriculture, Technology and

Sciences, Prayagraj, Uttar

Pradesh, India
Corresponding Author:

Ashwani Kumar

Associate Professor,

Department of Entomology,

Sam Higginbottom University of

Agriculture, Technology and

Sciences, Prayagraj, Uttar

Pradesh, India

\section{Evaluation of different insecticides on maize stem borer, Chilo partellus (Swinhoe)}

\section{Panuganti Shirisha and Ashwani Kumar}

\author{
DOI: https://doi.org/10.22271/j.ento.2021.v9.i4f.8810
}

\section{Abstract}

Management of Maize stem borer Chilo partellus (Swinhoe) using various insecticides in field condition was carried out during Kharif 2019-2020 at central Research field SHUATS Prayagraj, UP., India. The management of Maize Stem borer Chilo partellus (Swinhoe) was done using 8 different treatments and benefit cost ratios of all the treatments were calculated. Single spray was applied to protect the crop from Chilo partellus using randomized block design with three replications. The observations of Chilo partellus before 24 hours (Pre- treatment) and 3rd, 7th and 14th day after spraying (Post-treatment) were recorded for computing the percent of pest reduction. The data were subjected to statistical analysis after appropriate transformation for interpretation. The treatment with recommended insecticide Fipronil $0.3 \%$ $\mathrm{G}$ was of the most effective treatment followed with Carbofuran 3G and Spinosad 45\% SC The next best treatments were found to be Chlorantraniliprole $0.4 \mathrm{G}$, Cypermethrin $10 \%$ EC. Indoxacarb and Profenophos were found to be least effective against Chilo partellus (Swinhoe). The highest Benefit cost ratio was recorded with Fipronil (1:1.70) and Carbofuran (1:1.60) followed by the Spinosad (1:1.46), Chlorantraniliprole (1:1.39), Cypermethrin (1:1.28), Indoxacarb (1:1.15), Profenophos (1:1.07).

Keywords: Chilo partellus, fipronil, insecticides, Zea mays

\section{Introduction}

Maize (Zea mays L.) is an important cereal crop with high economic value after wheat and rice in the world ${ }^{[1,5]}$. Zea mays (Linnaeus) which belongs to family Poaceae. Maize, known as 'Queen of cereals' because of its immense yield potential, it is the highest yielding cereal crop of world ${ }^{[19]}$ and is particularly important in countries like India where food security is most vulnerable due to ever increasing population that has outnumbered the available resources. It has short growing season and is drought resistant that make it very easy to grow everywhere in different climatic conditions of the world ${ }^{[2]}$.

It is one of the most versatile crops grown under a wide range of agro-ecological locations of tropical, sub -tropical and temperate regions of the world. It is used as human food, animal feed, fodder, for production of starch, oil, liquor, dextrose and dyes etc. In India, about $28 \%$ of maize produced is used for food purpose, about $11 \%$ as livestock feed, $48 \%$ as poultry feed, $12 \%$ in wet milling industry (starch and oil production) and $1 \%$ as seed ${ }^{[19]}$.

Insect pest's infestation are causing a major threat to maize crop due to its high susceptibility throughout the crop duration. Maize plant is attacked by 140 species of insect pests causing varying degree of damage ${ }^{[18]}$. Many insect pests like maize stem borer, European corn borer, pink borer, shoofly, cutworms and aphid attack maize crop and adversely affect its production. Among them, maize stem borer Chilo partellus (Swinhoe) (Lepidoptera: Pyralidae) is most common destructive insect pests of maize crop ${ }^{[4,10]}$.

In general, the borer caused minor damage, pin holes on leaves. In severe cases, dead hearts are formed, the condition in which the plants do not bear any ear at all. At our context, till now, yield loss caused by maize stem borer yet to be estimated in combined with the relationship of stem tunnelling as well as leaf damage to monitory value. However, some researchers have reported that borer can culminate yield loss of 20-87\% ${ }^{[7,13]}$.

The stem borer attack can weaken the maize plant resulting in lodging as well as breaking and dead heart, which ultimately reduces maize yield. For effective management of stem borers infesting maize, effective chemicals and their timing of application (early whorl stage) is significant as this pest is internal feeder and control at different stage offers narrow scope for chemical control ${ }^{[16]}$. 
Application of various insecticides with different mode of action strengthen insecticide management resistance strategy. Thus, to demonstrate the pest management with different insecticide treatment is necessary. So, the best one can be identified for the management of Maize stemborer, through their comparative effective of chemical insecticides the present investigation was therefore undertaken with.

\section{Materials and Methods}

A Field experiment was conducted during Kharif 2019 at Central Research Field, Department of Entomology, SHUATS, Prayagraj (U.P.). The climate is typically semi-arid and subtropical. The maximum temperature reaches up to 48 $\mathrm{oC}$ in summer and drops down to -2 oC in winter. The site selected was uniform, cultivable with typical sandy loam soil having good drainage. The trial was laid out in Randomized Block Design. The experiment was carried out on Maize variety is King9999. It was sown with seed rate of 20$25 \mathrm{Kg} / \mathrm{ha}$ at spacing $60 \times 20 \mathrm{~cm}$. There were 8 treatments each replicated thrice. The treatments consist of Fipronil $0.3 \% \mathrm{G}$ (12Kg/ha), Carbofuran 3G (20Kg/ha), Spinosad $45 \% \mathrm{SC}$ (45g/ha), Chlorantraniliprole 0.4G (10Kg/ha), Cypermethrin $10 \% \mathrm{EC}$ (550ml/ha), Indoxacarb $14.5 \mathrm{SC} 500 \mathrm{ml} / \mathrm{ha}$ and Profenofos $40 \%$ EC (500ml/ha). Recommended doses of nitrogen, phosphorous and potassium were applied.

Application of treatments for the management of the Chilo partellus was initiated as soon as 5\% ETL of infestation observed in experimental field. The observation was recorded on weekly intervals throughout the cropping season. To assess the incidence of stem borer at weekly intervals the total number of plants and number of infested plants (number of dead hearts and pin holes present on the leaves) were counted from each plot. Observations on number of larvae were recorded on 3, 7 and 14 days of each spray and were subjected to statistical analysis.

\section{Results and Discussion}

The observations were recorded on weekly intervals throughout the cropping season. Different pest per plant was counted and recorded at weekly intervals on plants. The observations on number of stemborer were done by counting the number of dead hearts and pin holes present on leaves. While recording observations on stem borer the middle whorl of the plant was gently plucked and observed the pest. The data on percent of dead hearts showed that all the insecticides were significantly superior over control in reducing the infestation percent of stem borer which were recorded at 3,7 and 14 DAS mean after insecticidal application Fipronil was found significantly superior $(7.767 \%)$, these findings are supported by Deepak singh et al. ${ }^{[8]}$ and Singh et al. ${ }^{[19]}$ followed by Carbofuran $(9.400 \%)$ similar findings were also reported by Malav et al. ${ }^{[12]}$ and Devananda et al. ${ }^{[9]}$, Spinosad $(10.700 \%)$ was next best treatment these similar findings are with those of Karthikeyan et al. ${ }^{[11]}$ and Sarsawati et al. ${ }^{[17]}$, Next best treatment proved to be Chlorantraniprole (12.333\%) these similar findings are with those of Omprakash et al. ${ }^{[14]}$ and Pallavi et al. ${ }^{[15]}$, Cypermethrin (13.33\%) was found next best these similar findings are with those of Malav et al. ${ }^{[12]}$ followed by Indoxacarb (14.33\%) and Profenophos (14.35\%) these similar findings are with those of Wajid et al. ${ }^{[20]}$ and Amol et al. ${ }^{[3]}$ was found least effective when compared with other treatments given in Tableland graphical representation in Fig1.

\section{Conclusion}

Results showed that Fipronil $0.3 \% \mathrm{G}$ proved to be most effective and economical for managing maize stem borer damage due to their mode of action compared to other insecticides. Recommended dose of chemicals be useful in devising proper integrated pest management strategy against maize stem borer.

Table 1: Evaluation of different Insecticides treatments on the incidence maize stem borer (Chilo partellus) infestation after first spray.

\begin{tabular}{|c|c|c|c|c|c|c|}
\hline \multirow{2}{*}{ S. No } & \multirow{2}{*}{ Treatment } & \multicolumn{5}{|c|}{ Mean \%of Plant Infestation } \\
\cline { 3 - 6 } & Fipronil & 16.63 & 10.73 & 6.80 & 5.83 & 7.76 \\
\hline T1 & Carbofuran & 13.66 & 11.73 & 8.76 & 7.80 & 9.40 \\
\hline T2 & Spinosad & 17.60 & 13.70 & 9.76 & 8.76 & 10.70 \\
\hline T3 & Chlorantraniprole & 13.70 & 14.66 & 10.73 & 11.73 & 12.33 \\
\hline T4 & Cypermethrin & 12.70 & 15.66 & 11.73 & 12.73 & 13.33 \\
\hline T5 & Indoxacarb & 12.70 & 16.63 & 12.73 & 13.70 & 14.33 \\
\hline T6 & Profenophos & 13.66 & 17.60 & 12.70 & 12.70 & 14.33 \\
\hline T7 & Control & 13.66 & 15.66 & 15.63 & 23.46 & 18.20 \\
\hline T0 & F- TEST & NS & S & S & S & S \\
\hline & S-Ed & 1.118 & 0.878 & 0.876 & 0.998 & 0.853 \\
\cline { 2 - 6 } & CD & - & 4.055 & 4.036 & 5.24 & 3.82 \\
\cline { 2 - 6 } & & & & & & \\
\hline
\end{tabular}




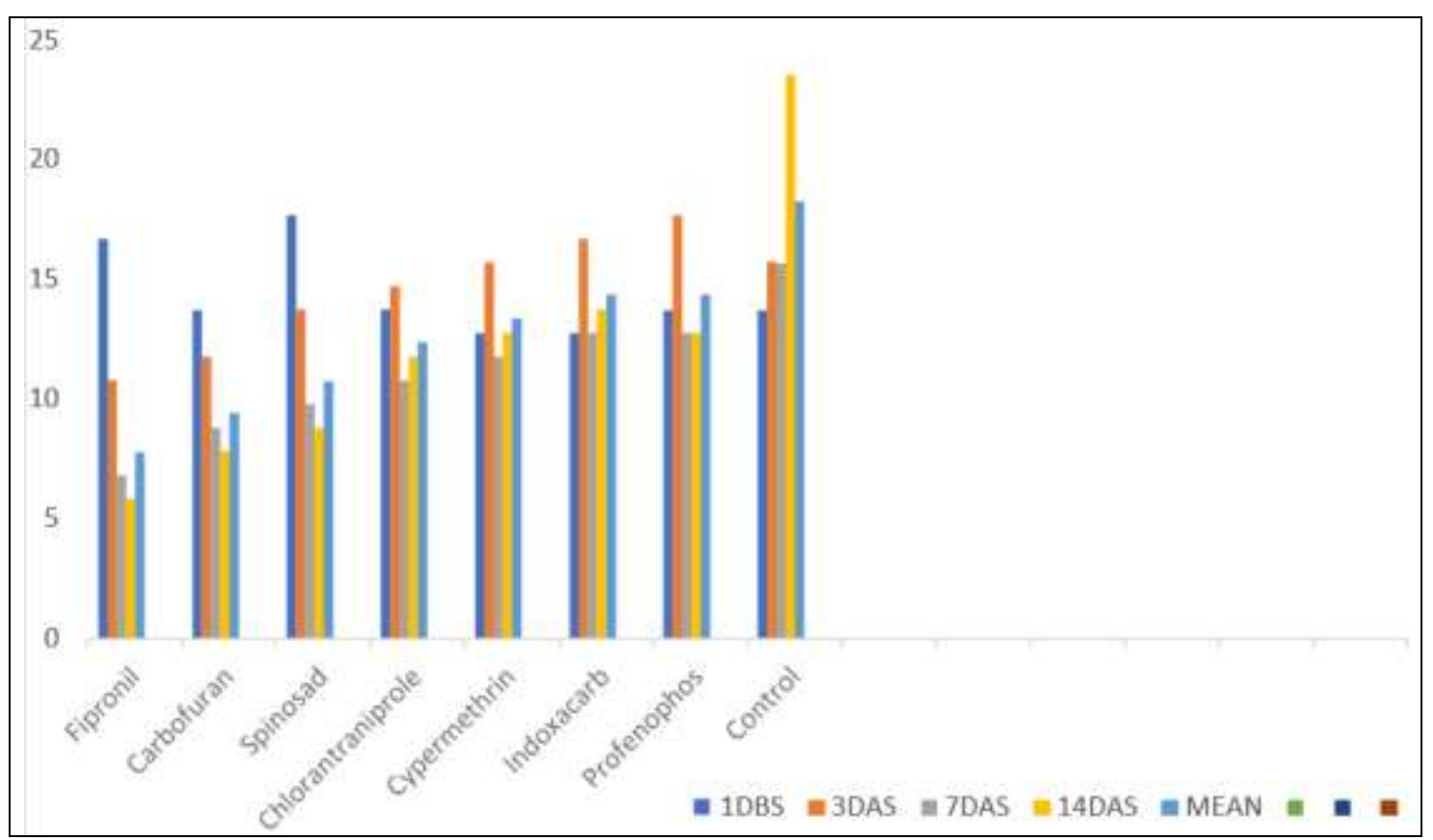

Fig 1: Graphical representation on evaluation of different insecticides on maize stem borer after first spray

Table 2: Evaluation of different Insecticides on Maize stem borer (Chilo partellus) percent mean reduction.

\begin{tabular}{|c|c|c|c|c|c|c|c|}
\hline \multirow{2}{*}{ S. No } & \multirow{2}{*}{ Treatment } & \multicolumn{6}{|c|}{ \%Mean reduction } \\
\cline { 3 - 8 } & Fipronil & 16.63 & 10.73 & 6.80 & 5.83 & 7.76 & \%Mean Reduction \\
\hline T1 & Carbofuran & 13.66 & 11.73 & 8.76 & 7.80 & 9.40 & 48.36 \\
\hline T2 & Spinosad & 17.60 & 13.70 & 9.76 & 8.76 & 10.70 & 41.20 \\
\hline T3 & Chlorantraniprole & 13.70 & 14.66 & 10.73 & 11.73 & 12.33 & 32.2 \\
\hline T4 & Cypermethrin & 12.70 & 15.66 & 11.73 & 12.73 & 13.33 & 26.75 \\
\hline T5 & Indoxacarb & 12.70 & 16.63 & 12.73 & 13.70 & 14.33 & 21.26 \\
\hline T6 & Profenophos & 13.66 & 17.60 & 12.70 & 12.70 & 14.35 & 21.15 \\
\hline T7 & Control & 13.66 & 15.66 & 15.63 & 23.46 & 18.20 & 0 \\
\hline T0 & F- TEST & NS & S & S & S & S & \\
\hline & S-Ed & 1.118 & 0.878 & 0.876 & 0.998 & 0.853 & \\
\cline { 2 - 7 } & CD & - & 4.055 & 4.036 & 5.24 & 3.82 & \\
\cline { 2 - 7 } & & & & & & \\
\hline
\end{tabular}

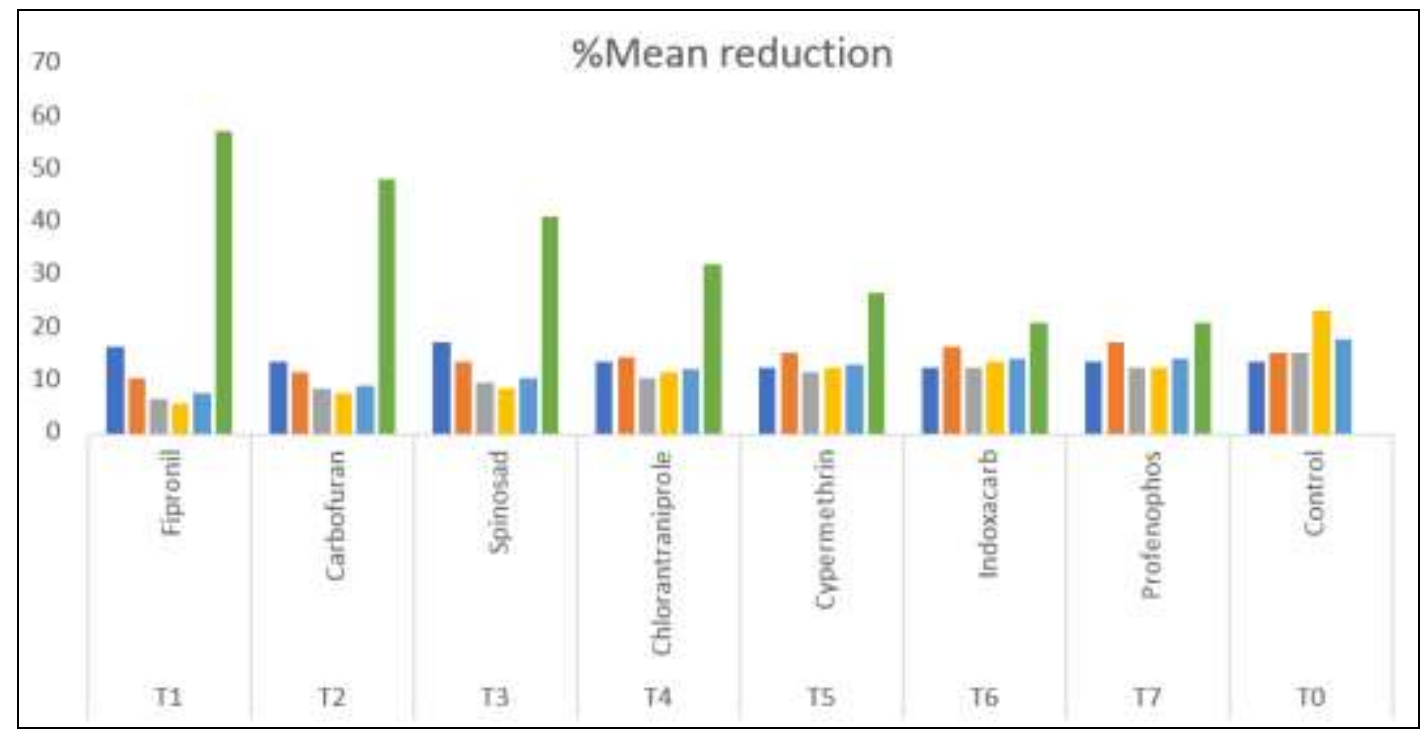

Fig 2: Graph representing the \% Mean reduction

\section{Acknowledgement}

The author expresses her heartfelt gratitude to Dr. Ashwani Kumar, Associate professor, Department of Entomology and Prof. (Dr.) L. Sobita Devi, Head of the Entomology department, Sam Higginbottom University of Agriculture Technology and Sciences, Prayagraj, U.P. for their excellent guidance, suggestions and regular encouragement during the course of investigation. 


\section{References}

1. Ahmed S, Anjum S, Naeem M, Ashraf MY. Determination of efficacy of Cypermethrin, Regent and Carbofuran against Chilo partellus Swin. and Biochemical changes following their application in maize plants. International Journal of Agriculture \& biology 2003;5(1):30-35.

2. Amin MEMH. Effect of different nitrogen sources on growth, yield and quality of fodder maize (Zea mays L.). Journal of the Saudi Society of Agricultural Sciences 2011;10(1):17-23.

3. Amol MK, Patel KG. Yield Performance of Different Insecticides against Rice Yellow Stem Borer, Scirpophaga incertulas WLK. Rice research 2019;7:1.

4. Andow DA, Hilbeck A. Environmental risk assessment of genetically modified organisms. A case study of $\mathrm{Bt}$ Maize in Kenya, CABI Publishing, Wallingford, UK 2004, 57-82.

5. Atwal AS, Dhaliwal GS. Agricultural Pests of South Asia and their Management, 5th edn, Kalyani Publisher, New Delhi 2007.

6. Bukhsh MAAHA, Ahmad R, Ali A, Ishaque M, Rehman A. Potassium use efficiency of maize hybrids. Journal of Animal and Plant Sciences 2012;22(3):728-32.

7. Chatterji SM, Young WR, Sharma GC, Sayi JV, Chabai BS, Khare BP. Estimation of loss in yield of maize due to insect pests with special reference to borers. Indian Journal of Entomology 1969;31:109-115.

8. Deepak S, Ajoy KS, Ashish K. On-farm Evaluation of Integrated Management of Rice Yellow Stem Borer (Scirpophaga incertulas Walk.) in Rice-Wheat Cropping System under Low Land Condition. Journal of AgriSearch 2014;1(1):40-44.

9. Devananda AV, Khanpara, Vaja AM. Bio-efficacy of various insecticides against maize stem borer Chilo partellus (Swinhoe) Crambidae: Lepidoptera in Junagadh conditions. Journal of Pharmacognosy and Phytochemistry 2018;7(4).

10. Groote H, Overholt WA, Ouma JO, Wanyama J. Assessing the potential economic impact of Bacillus thuringiensis (Bt) maize in Kenya. African Journal of Biotechnology 2011;10(23):4741-51.

11. Karthikeyan K, Sosamma J, Purushothaman, Smitha R. Effect of spinosad against major insect pests and natural enemies in rice ecosystem. Journal of Biological control. 2008;22(2):315-320.

12. Malav SK, Lyall Sharma H, Sharma AK, Himanshu VM. Efficacy of certain chemical insecticides and neem oil against stem borer (Chilo partellus Swin) on maize (Zea mays L.) International Journal of Advanced Scientific Research and Management 2018.

13. Mathur LML. Advances in insect pest management in maize. In: G.S. Dhaliwal and Ramesh (eds.), Trends of agriculture insect pest management, common wealth publisher, New Delhi, India 1994, 113-160.

14. Omprakash Venkataiah $\mathrm{M}$, Laxman S. Comparative efficacy of some new insecticides against rice yellow stem borer, Scirpophaga incertulas Walker under field conditions. Journal of Entomology and Zoology Studies 2017;5(5):1126-1129.

15. Pallavi Sharanabasappa D, Girijesh GK. Evaluation of newer insecticide molecules against rice stem borer Scirpophaga incertulas on paddy. International Journal of Chemical Studies 2018;6(2):2551-2554.
16. Ravinder K, Jawala J. Economic evaluation of biorational and conventional insecticides for the control of maize stem borer Chilo partellus (Swinhoe) in Zea mays. Journal of Applied and Natural Science 2015;7(2):644648.

17. Saraswathi N, Ghanashyam B, Sheela DS, Surendra Y, Subash S. Management of stem borer (Chilo partellus Swinhoe) in maize using conventional pesticides in Chitwan, Nepal. Journal of Maize Research and Development 2016;2(1):13-19.

18. Sarup P, Siddique KH, Marhawa KK. Trends in Maize pest management research in India together with bibliography. Journal of Entomological Research 1987;11(1):19-68.

19. Singh C, Singh R, Singh P. Modern Techniques of Raising field Crops. Oxford and IBH publishing Company Pvt. Ltd. New Delhi 2012, 84-111.

20. Singh P, Rajendra S, Dhaka SS, Deepak K, Hitendra K, Neelam K. Bio efficacy of insecticides and bio-pesticides against yellow stem borer, Scirpophaga incertulus (walk.) and their effect on spiders in rice crop. South Asian Journal of Food Technology Environmental 2015;(2):179-183.

21. Wajid H, Chhibber RC, Singh CP. Effect of Indoxacarb against Tomato Fruit Borer (Helicoverpa armigera Hub.) and Phytotoxicity to Tomato Plants. Advances in plants and Agriculture research 2016. 